\title{
The Role of Liturgical Hymns within the Sacramental Mysticism of St. Nicholas Kabasilas
}

\section{Dragoş Ioan ŞUŞMAN *}

Abstract: The present study makes a journey into the sacramental mysticism of St. Nicholas Kabasilas. His liturgical commentary is considered the peak of Byzantine theological interpretation of the Holy Liturgy. The most impressive feature of his work is its coherence: the Byzantine mystic presents the whole liturgical edifice of the Church as being presided by, and revolving around Christ. According to Kabasilas, the role of the divine service is to mediate the encounter between the Good Shepherd and his sheep, this encounter is meant to provide palpable consistency to the Church. From this perspective, the liturgical hymns become real stairs leading the believers towards the ultimate meeting with Christ in the Holy Communion.

Keywords: music, mystic, liturgy, divine service, Eucharist, Hesychasm.

Taking into consideration the main features of Hesychast mysticism, dinamising the entire sprirituality of Eastern Orthodoxy, St. Nicholas Kabasilas (approx. 1320- 1398) declared that ,life in Christ"- the highest form of spiritual fulfillment accesible to any Christian in this world- can only be lived within the Church, being transmitted to us through the Holy Sacraments.

* PhD, Rev Lecturer, Faculty of Orthodox Theology, "1 Decembrie 1918" University from Alba Iulia. 
The Byzantine mystic defines the holy Sacraments as fundamental acts of Christian life, through which an authentic spiritual experience is communicated to us, revelating a real presence at the same time: ,Due to the Holy Mysteries - which portray to us the burial of the Lord and proclaim His death - we are also born to the spiritual life; with their help we grow in it and we come together to marvelously unite with our Savior Himself. For through these holy works we "live and move and have our being "(Acts 17,28) as Saint Paul said." I

The special merit of St. Nicholas Kabasilas resides in the fact that he managed to express with great clarity that "life in Christ" is communicated to the believers through their active and conscious participation to the sacramental and liturgical life of the Church, this life having as a principle and charismatic source the divine altar. By responsibly assuming "life in Christ", the Christian is offered the possibility to overcome spiritual anonymity and cultural poverty, a state in which he is inclined to fall, once he starts living outside the sacramental and liturgical environment of the Church. According to Kabasilas, "The Church is embodied in the Holy Sacraments not in a symbolic way, but as parts of the same heart, as the branches in the root of the plant, or, as the Savior says, as the branches of the vine. So, this is not just a community of names or just a similarity between them, but a true identity. This is because the sacraments are the Body and Blood of the Lord, but they are also the food and the true drink of the Church of Christ". ${ }^{2}$ The Church is being built, perfected and revealed through the Holy Sacraments, especially through the

${ }^{1}$ Nicolae CaBasila, Despre viaţa în Hristos (About life in Christ), Ro. transl.. Pr. Prof. Dr. Teodor Bodogae, Bucharest, Editura Institutului Biblic, 1997, p. 29-30.

${ }^{2}$ Nicolae CABASIlla, Tâlcuirea dumnezeieştii Liturghii (Explanation of the Divine Liturgy), Ro. transl.. Pr. Prof. Dr. Ene Branişte, Bucharest, Editura Institutului Biblic, 1997, p. 89. 
Divine Eucharist, "the highest peak of spiritual life. ${ }^{13}$ The sacraments represent the royal path through which "men become gods and sons of God, and our human nature, which is otherwise dust and ashes, is worthy of the honor which only God owes to itself, rises to such magnification that it becomes partaker of the very honor and divine nature". 4

The Divine Eucharist, being the Mystery of the real presence of our Savior Jesus Christ, has this unique character in our entire sacramental and spiritual life. Through this Mystery, the One Sacrifice of the Cross becomes contemporary and accessible to every believer, so that he can assume, in the most realistic possible way, the saving fruits of this sacrifice, applying it to his own life. Due to the fact that the divine Eucharist is committed and offered only within the liturgy, Kabasilas felt obliged to develop a liturgical hermeneia that would become normative for Orthodoxy. Kabasilas' Hermeneia is considered the highest peak of Byzantine theological writing in the field of Liturgy interpretation. ${ }^{5}$ In this work the Divine Liturgy is understood and interpreted as an authentic environment in which the spiritual preparation of the liturgists and believers for the great act of unity with the Christ- Eucharistic is gradually achieved. ${ }^{6}$

By saying "the celebration of the Divine Liturgy has as its object the transformation of the gifts into the divine Body and Blood, and as a purpose the sanctification of the believers, who through these acquire forgiveness of sins and inherit of the

${ }^{3}$ Nicolae CABASILA, Despre viaţa în Hristos..., p. 106.

${ }^{4}$ Ibidem, p. 33.

5 Ene BRANIȘTE, Explicarea Sfintei Liturghii după Nicolae Cabasila (Explanation of the Divine Liturgy according to St. Nicholas Kabasilas), Bucharest, Edit. Institutului Biblic, 1997, p. 371.

${ }^{6}$ Ibidem, p. 257-275. 
kingdom of heaven"7, Kabasilas draws from the beginning the fundamental line of the mystagogic perspective. The various elements that come into the composition of the liturgical order are presented as auxiliary means that contribute to our spiritual opening, infusing us with the real presence of our Savior: "And the means that prepare and facilitate the fulfillment of that effect and purpose are prayers, songs, readings from the Holy Scripture and, in general, all that is done and spoken with holy ordinance before and after the consecration of the Gift". ${ }^{8}$ Through this interpretation of the Divine Liturgy, Kabasilas' hermeneia offers the basics of a theology of hymnography and liturgical singing, especially with regard to their purifying and sanctifying function.

\section{The sanctifying function of liturgical singing}

Not only does the Byzantine mystic explain the nature of the spiritual life, but he also considers those ritual elements through which the believer prepares himself for the solemn encounter with Christ- Eucharist, "the highest target to which human endeavor can be directed". 9

As a teacher of sacramental and liturgical mysticism, St. Nicholas Kabasilas knew how to direct Christian piety towards its true source, the union with the incarnate Christ. To reach the highest threshold of "life in Christ," - the Eucharist- it is necessary to purify our being through a preparation process. The call that God makes in His goodness, namely, "in fear of God, with faith and with love draw near." - only works in synergy with our freedom and responsibility. So, "we must not give up in the face of any suffering and hardship, but with all the sweat of our

${ }^{7}$ Ene BRANIȘTE, Tâlcuirea dumnezeieştii Liturghii (Explanation of the Divine Liturgy)..., p. 7.

${ }^{8}$ Ibidem.

${ }^{9}$ Nicolae CaBasila, Despre viaţa în Hristos..., p. 110. 
brow, let us feed upon this Bread that was broken especially for us -since it breaks only for rational beings and becomes eternal food - (see John 6:27). But the gift of this wonderful feast cannot come to us in vain and laziness, but after difficult endeavors. For, if Paul forbids the lazy people receive even ordinary food: "The one who is unwilling to work shall not eat." (II Thess. 3:10), then how many endeavors do we need to make us worthy of a holy meal like this?"10

The actual sanctification (having an objective character) which we acquire through the reception of the divine Eucharist, must be necessarily preceded by the preparatory sanctification (with subjective character) and is fulfilled in the plan of our will and responsibility. As Kabasilas' says: During the transformation of the Eucharistic Gifts into the divine Body and Blood of Christnothing of our human weakness can prevent the work of Grace, since their sanctification is not the work of human virtue; but when it comes to of the purpose of the Liturgy- sanctification of the faithful- the work of the Divine Grace can be obstructed because of our own sins and ill will. "Grace sanctifies us through the Holy Gifts only if it has found us ready for sanctification, but if we have been found unprepared, it does not bring us any gain, but on the contrary it causes us an immense damage. "11

The sanctification preceding the union with Christ has a synergic character and is accomplished in two directions: a) the purification of the soul from all sin and growth in virtue; b) participation to the Divine Liturgy, the sacramental environment in which the Body and Blood of Christ is offered "for the forgiveness of sins and everlasting life." The first direction culminates in the Confession, which brings the human being into

${ }^{10}$ Ibidem, p. 128. Also see: Tâlcuirea dumnezeieştii Liturghii (Explanation of the Divine Liturgy), p. 85-86.

${ }^{11}$ Tâlcuirea dumnezeieştii Liturghii (Explanation of the Divine Liturgy), p. 82. 
a state of grace- the normal spiritual state for Eucharistic communion.

As a sacramental medium through which we receive the actual sanctification, the Divine Liturgy has the means that make possible the preliminary purification that must necessarily preempt the sanctification brought by the communion with the Body and Blood of the Savior. This is the context in which St. Nicholas Kabasilas places liturgical hymnography and liturgy together, giving them special importance.

The first chapter of his hermeneia points out that the ultimate goal of Divine Liturgy is to sanctify believers by sharing the Eucharist. He shows the special means that make the preparatory sanctification possible, and at the same time- the way to apply this in our spiritual life: "The means which prepare and facilitate the fulfillment of that effect and purpose are prayers, songs, readings in the Sacred Scripture and, in general, all the things done and worded with holy ordinance before and after the consecration of the gifts. It is true that God gives us all the sacred gifts, without we giving Him anything in return; however, He is necessarily asking us to be worthy to receive and keep them, for He only sanctifies those who have been prepared in this way. This is the way to receive Baptism and Chrismation, this is the way to partake at the feast of the King's table."12 To reinforce his statement, Kabasilas refers to the sower's parable, in which the Savior resembles souls with a field to be prepared to receive the seed and to germinate. Such preliminary preparation is also necessary for the "seed" of the Divine Grace, which is shared through the Holy Mysteries, to be able to bring forth fruit in the spiritual life. The Savior had this fundamental principle in mind when He said, "A farmer went out to sow his seed" (Matthew 13:

${ }^{12}$ Ibidem, p. 7. 
3) not to plow the land, letting us understand that the plowing and all the preparation must be done in advance ". ${ }^{13}$

By virtue of this principle, "upon receiving the divine Mysteries - it is of utmost importance to present ourselves prepared and worthy. Therefore, in the service of the Divine Liturgy, there must also be means of preparation: the prayers, the songs and all that is done, or uttered in it, according to the holy ordinance. These sanctify us and enable us, on the one hand, to be worthy of receiving holiness, and on the other hand, to be able to keep it and stay with it."14

St. Nicholas Kabasilas argues that the preliminary sanctification that makes us worthy to receive the divine Eucharist is accomplished in two complementary ways: charismatic-moral and symbolic-mystical. "First we are purified, through the very power of prayers, songs and readings. Thus, prayers turn our minds to God, interceding for the forgiveness of our sins, the songs also make Him have mercy on us ...; Finally, the reading of Holy Scripture, which teaches us both the goodness and God's love for the people, and His righteousness and justice. They all sow and ignite in our souls not only love but also fear of Him, thus making us more zealous in keeping His commandments. All these together, improve the soul and draw near to God both the priest and the people, making them able to receive and preserve the sacred gifts, -the purpose of the Divine Liturgy. But they prepare the priest in particular to commit the Sacrifice, which is the effect of the Divine Liturgy. This is how we are prepared for the holy work of the words spoken and sung". ${ }^{15}$

The idea of the sanctifying function of prayers, hymns and biblical readings within the Divine Liturgy might have been taken

\footnotetext{
${ }^{13}$ Ibidem.

${ }^{14}$ Ibidem.

${ }^{15}$ Ibidem, p. 8.
} 
from St. Dionysius of Areopagus. He said that those who are perfected by sharing the divine Eucharist "the sacred songs and readings of the Scriptures give them the teaching of virtuous life and, before that, the total cleansing of the sin of corruption."16

In his interpretation, "the hymn that encompasses all the holy things prepares our soul powers for harmony with those that will be sanctified a little later, and by the omophonic execution of divine hymns, this will produce the common understanding of the divine and that of one another, like through a united chorus and a common confession of the holy, the most concentrated and vague ideas in the utterance of the words of psalms, become more clearly understood by more and more clear representations; and their expression or understanding is widened by clear reading of written texts. In them, the one who opens his eyes to holiness will live a unitary breath as moved by the One and Divine Spirit". ${ }^{17}$

This is why the sanctifying work of ritual elements is also accessible to those who are preparing to receive the sacraments of Christian initiation, which can only be received during the first part of the Liturgy: "catechumens, energums and those in repentance are allowed by the holy hierarchy to hear the holy song of the psalms and the divine readings from the Scripture. But they are not invited to partake to the holy works and spiritual views that follow, because these are only for the purified eyes of the believers." 18 As for the mysterious work of the Divine Chrism, Saint Dionysius the Areopagite says that "the songs and readings from the Scripture prepare for rebirth the people who have not yet been purified in order to become children of God, and how they cause the holy return of those who are ruled by evil,

${ }^{16}$ Sfântul Dionisie AREOPAgitul, Despre Ierarhia Bisericească (About the Church Hyerarchy), in Opere complete, transl. introd. and notes by Pr.

Prof. Dr. Dumitru Stăniloae, Bucharest, Edit. Paideia, 1996, p. 79.

${ }^{17}$ Ibidem, p. 80.

${ }^{18}$ Ibidem. 
or removes the fear and the pleasant attractions from the energumians ${ }^{19}$ and shows them the power of the divine image as much as they can receive. By this, they will be able to frighten the opposing powers, and bring healing to others ... those who have abandoned evil deeds and gained a purified mind are given holy knowledge to no longer be overcome by sins. Those who are not yet entirely sanctified, are now cleansed completely, while the holy ones are taken to see and communicate with the divine presence. Finally, the sanctified ones are kept in happy and spiritual communion filling them and unifying them with the One". ${ }^{20}$

St. Maximus the Confessor also understanding the Liturgy as a mystical environment in which union with God is made, says that "the spiritual sweetness of divine songs indicates the joy that reveals the communion with the divine goodness, on the one hand, moving the souls towards pure and happy love of God, and, on the other, it inspires them even more to hate sin. ${ }^{21}$.

\section{The symbolic-mystical function of liturgical hymns}

St. Nicholas Kabasilas has a special contribution to the symbolic-mystical perspective of interpreting the ritual elements of the Divine Liturgy. In his opinion, "prayers, songs, and all the things that happen during the holy service, sanctify us by helping us see Christ with our inner eye: His work and Passion for us ... Indeed in songs, readings, and in all the things performed by the

${ }^{19}$ As St Maximus the Confessor mentions in his explanation to this word, the „energumenos" are ,those possessed and inclined towards lust”. Cf. Ibidem, p. 112.

${ }^{20}$ Ibidem, p. 86.

${ }^{21}$ Sfântul MAXIM MĂRTURISITORUL, Mystagogia, Ro. transl.. şi prezentare Pr. Prof. Dr. Dumitru Stăniloae (cu titlul Cosmosul şi sufletul, chipuri ale Bisericii) în „Revista Teologică” (Sibiu), XXXIV (1944), nr. 7-8, p. 339. 
priests throughout the service, the delivering work of the Savior is symbolized. "22

Kabasilas states that these readings and songs, which conceive the saving work of Christ, may encourage believers towards virtue. In order to make it better understood, he appeals to an example from everyday life: "clothes, satisfy first of all the need for clothing, covering the body, but, being tailored in one way or another, they often mirror the occupation, way of life or rank of those who wear them. The same is true for the ordinance of the Holy Liturgy: of course, the Holy Scriptures, encompassing God's words of inspiration and praise for God, exhort virtue and sanctify those who read and sing them; but being chosen and ordered in a certain way, they also have another purpose, that is, they can imagine the incarnation and earthly work of Christ. The same can be said not only of hymns and reading, but also of sacred ceremonies: each of them is performed for a certain purpose, but at the same time symbolizes something of the works, deeds or passions of Christ. "23

Analyzing the ritual elements (prayer, singing, reading in Holy Scripture) through which the believer prepares for the solemn encounter with the Christ Eucharist, it is noticed that the sacramental or liturgical life has a profound mystical nature. By interpreting the Liturgy as a sacramental environment in which union with Christ is achieved, Kabasilas also takes into account its contemplative-mystical character. In this sense, he states that the elements that are part of the Liturgy, among which the chants consecrated by the Church, are "means of cleansing and preparation for receiving the Holy Mysteries". ${ }^{24}$

${ }^{22}$ Ene BRANIȘTE, Tâlcuirea dumnezeieştii Liturghii (Explanation of the Holy Liturgy), p. 8.

${ }^{23}$ Ibidem, p. 9-10.

${ }^{24}$ Ibidem, p. 42. 
The entire path of preliminary sanctification that leads the faithful to the "highest peak of spiritual life" is marked by those liturgical exclamations and exhortations that Kabasilas considers to be integrated in the same mystical context as prayers, chants and Bible readings. The "let us attend" preceding the reading of the Epistle represents for Kabasilas a formula by which "the priest urges all to remember what is being done and sung". ${ }^{25}$ Attention, awake state, guarding the heart, guarding the mind are expressions familiar to the ascetic vocabulary, having the same meaning. Between attention and prayer there is an intimate relationship that has been highlighted by the treatises of the philokalists. In this respect, Evagrios from Pontus (345-399) whose teaching was not alien to Kabasilas, said: "Attention in pursuit of prayer will find prayer, for if there is a thing that follows prayer, that is attention. And we have to work to achieve $i t "{ }^{26}$ Also Saint Simeon The New Theologian, in his Method of Sacred Prayer and Attention, says: "Wisdom and prayer are bound together as soul and body, if one lacks, the other can not stand. ${ }^{127}$

Being aware of the dangers of a scattered mind for those who take part in the Divine Liturgy, St. Nicholas Kabasilas tries to find in the structure of the Liturgy elements that can fulfill the function of a "holy prayer and attention" method. In this sense,

${ }^{25}$ Ibidem, p. 52.

${ }^{26}$ Evagrie Monahul, Cuvânt despre rugăciune (Sermon about prayer), in Filocalia, vol. 1, Ro. transl.by Pr. Prof. Dr. Dumitru Stăniloae, Sibiu, Institutul de Arte Grafice „Dacia Traiană”, 1947, p. 92. See also Tomáš Spidlik, Spiritualitatea Răsăritului Creştin. II.Rugăciunea (Spirituality of the Eastern Christianity Vol. II. Prayer), Ro. transl.. Diac. Ioan I. Ică jr., Sibiu, Edit. Deisis, 1998, p. 317.

27 Sfântul SimeOn Noul TEOLOG, Metoda sfintei rugăciuni și atenții (The method of holy prayer and attention), în Filocalia, vol. 8, transl. introd. and notes Pr. Prof. Dr. Dumitru Stăniloae, Bucharest, Edit. Institutului Biblic, 1979, p. 528. 
he says that the "Righteous" exclamation in the formula preceding the gospel reading "contains a goad" like many other expressions of this kind, urging us "who draw near to God and the Holy Mysteries, to pay attention, without laziness, but with excitement and all goodness to have this conversation [with God] whether we look, speak or listen to the holy words, and the first proof of our zeal and piety is the straight stature of our body (not sitting down but standing). This is the proper pose of those who pray, of servants who are paying attention to the sign of the Lord, so that they may rush to serve as soon as they are commanded." (see Psalm 122, 1-2). ${ }^{28}$

The liturgical exclamations have the role of maintaining the state of spiritual vigilance, in order to awaken the souls "the thoughts which we are due to have during the holy service, and with which we must look and listen to what is done and said, the thoughts full of faith, with nothing mundane in themselves." The remembrance work that liturgical exhortations accomplish is necessary "because the power of forgetfulness is great, and none of the human weaknesses can so easily enslave a man as it can. But we have to stand and take part to the service, songs and ceremonies, with proper thoughts, unless we want to waste our time and partake in vain". However, it is not easy to "stay awake and with a tense mind by our own will... so, we need an outside reminder in order to take control of our thoughts again, since thoughts are constantly stolen by oblivion and lured towards the vain daily worries". 29

Preliminary preparation or sanctification of the priests and believers has a subjective character, and is achieved through the intercession of hymns. As the climax of the Divine Liturgy

${ }^{28}$ Ene BRANIŞTE, Tâlcuirea dumnezeieştii Liturghii (Explanation of the Divine Liturgy), p. 53.

${ }^{29}$ Ibidem, p. 52. 
approaches - performing the Sacrifice and the Eucharistic communion - this preparation grows in intensity, so that at the sanctification of the Gifts and their transformation into the divine Body and Blood of the Savior, the priest and the believers are ideally speaking - "prepared in the most beautiful and holy form " 30

\section{Spiritual hymns - a meeting point between sacramental mysticism and Hesychast mysticism}

Orthodox liturgical experience shows that by participating in the Divine Liturgy, believers gain a great spiritual profit, even if they do not share the "divine, holy, most pure, immortal, heavenly and life-creating, fearful Mysteries of Christ". They receive the work of Christ, Whose presence is felt throughout the Liturgy, Whom we can meet through prayers, songs and readings from the Holy Scripture, by the irradiation of His sanctifying power that is connected to the mystical function of the Divine Altar. Consequently, Orthodox liturgical theology speaks of a "participation in spirit" to the Liturgy, which itself represents a way to unite with God, through knowledge and love.

In the following paragraphs we will try to identify points of convergence between the mystic "life in Christ" and the Hesychast mysticism of liturgical chanting.

Metropolitan Theoleptos of Philadelphia (1250-1321 / 26), the precursor of the theological and sacramental rebirth initiated by Saints Gregory Palamas and Nicholas Kabasilas ${ }^{32}$, in his

${ }^{30}$ Ibidem, p. 63.

31 According to Petre VINTILESCU, Liturghierul explicat (Hieratikon Explained), Bucharest, Editura Institutului Biblic, 1972, pp. 331-335.

32 See Dumitru STĂNILOAE, „Mitropolitul Teolipt al Filadelfiei. Viaţa şi scrierile (The Metropolitan Theoleptos of Philadelphia, Life and Works)", in Filocalia, vol. 7, Bucharest, Editura Institutului Biblic, 1977, p. 35-42. 
words "about the labors of monastic life" draws attention to the state of trepidation and concentration that the monk is expected to have while he prays: "be careful while you think you are praying, not to walk away from prayer, working without gain and running in vain. This happens when you sing with your mouth, but your mind is carried elsewhere, and it is divided between passions and things. Then, the meaning of the hymns themselves is diminished and tainted..." 33 In order to be of spiritual use, singing, just like prayer, must fulfill certain ascetic requirements: "Sing with your mouth. But in a quiet voice and watch your thoughts, concentrate on every word that is being said. And, if your mind loses track of something, repeat the verse whenever that happens until you have your mind accompanying what you are saying. For the mind can both sing with its mouth and keep the memory of God within. You can understand this from daily experience. When a person meets another, he can both talk, and examine the other with his eyes. In the same way, he who sings with his lips can also stay with God through attention. "134 When a monk takes part with his brethren in church, he must watch his thoughts, concentrate and integrate into the liturgical work of the community: "... then entering the church and integrating the community, do not speak with the one next to you, nor wander with your mind in vain, but only instruct your tongue to sing, and guide your thoughts towards prayer. "35

In his sermon "About the hidden work in Christ," Metropolitan Theoleptos formulates a "ladder" of spiritual chanting, its "steps" forming a mystical fight towards God: "if you know what you sing, you receive knowledge, and from knowledge you gain understanding; from understanding blossoms

33 „Cuvântul lui Teolipt, mitropolitul Filadelfiei, despre ostenelile vieții călugărești (The sermon of St. Theoleptos of Philadelphia about the hardsgips of monastic life)", în Filocalia, vol. 7, ed. cit., p. 55.

${ }^{34}$ Ibidem, p. 62-63.

${ }^{35}$ Ibidem, p. 64. 
the work of the things known, from which takes shape the fruit of knowledge through separation, the knowledge through experience gives birth to the true vision. Wisdom springs from it and is manifested in words of grace that spread light, because wisdom fills the essence of thought and interprets it to the outsiders". ${ }^{36}$

St. Gregory from Sinai $(1255-1346)^{37}$ understands the natural need to alternate Jesus' prayer and liturgical chanting, especially for those at the beginning of the hesychast experience: "If you sit down by day or night seeking peace and praying God frequently, without outside thoughts, in humility, but suddenly the mind is not able to cry anymore, and your body or heart starts aching from the strong attachment of repeatedly calling the name of Jesus; when you no longer feel the warmth, and no longer rejoice, and therefore have no will or patience - stand up and sing alone or with a disciple!... When you stand and sing alone, you can even say the Trisagion. Then pray again with your soul or understanding, the mind paying attention to the heart, and if you struggle with laziness, also say two or three psalms and two repentance verses, without melody..." 38

However, in order to reach the work of pure prayer, it is necessary to limit the practice of singing: "you should follow the ones who do little singing, because good measure is essential in everything, according to the wise fathers. Long chanting is for those who are tired from hard manual labor, to lift their spirit

36 TeOLIPT AL FILADELFIEI, „Cuvânt despre lucrarea cea ascunsă întru Hristos (About the hidden work in Christ)", in Filocalia, vol. 7, ed. cit., p. 71.

37 According to Pr. Prof. Dr. Dumitru Stăniloae, Sfântul Grigorie Sinaitul. Viaţa lui (St. Gregory of Sinai. His Life), în Filocalia, vol. 7, ed. cit., p. 7584.

38 Sf. Grigorie Sinaitul, Despre liniștire și despre cele două feluri ale rugăciunii( About seeking peace and the two types of prayer), în Filocalia, vol. 7, ed. cit., p. 179. 
and chase ignorance away, not for the ones who seek peace, those who dedicate their time to God, praying in their heart, and refraining from thoughts ... For, if a monk puts all the efforts of his mind, all his strength, in many scales, his spirit weakens and he will no longer be able to pray with power and diligence." 39

The same holy father establishes a daily program for monks, based on the alternation of three works - singing, praying and reading: "He who seeks peace is first to have as foundation these five virtues on which to build his edifice: silence, restraint, vigil, humility and patience. And, as good activities that may lift him towards God, he must have these three: singing, praying and reading; if he lacks strength, he should add the work of his hands. [...] He must occupy himself in the morning with the remembrance of God through prayer and with the calming of the heart. In the first hour he must pray with all his strength; in the second he must read; then he will dedicate the third hour to chanting; the fourth to prayer; the fifth to reading; the sixth to singing; in the seventh he will start praying again; reading in the eighth; singing in the ninth; the tenth hour is for eating; the eleventh for sleep if he needs it; in the twelfth hour he will sing the evening song. And so, following this routine with diligence, he will please God."

The few excerpts that I have presented are sufficient to show that sacramental mysticism and Hesychast mysticism meet

${ }^{39}$ Ibidem, p. 189-190.

40 Sfântul GrigorIE SinAITUl, "Capete foarte folositoare in acrostih (Very useful chapters in acrostic)", in Filocalia, vol. 7, ed. cit., p. 126. As we can observe, St Gregory advises that prayer, reading and singing should be repeated three times. Basically, we see three different ways in which a monk will keep his mind connected with God. Alternating them facilitates a better focus of his attention on the spiritual meanings of the word, be it written, spoken or sung. 
and naturally congregate in the sacred horizon of Christ's working presence in and through the Holy Spirit. This horizon also becomes accessible to our powers of comprehension with the help of church hymnography.

\section{Conclusions}

The consistency with which St. Nicholas Kabasilas highlights the role of religious singing in the spiritual life of every Christian proves that his trail of thought stems from life experience. It is the experience of the maternal love of the Church, who leads her sons, through divine worship, towards the encounter with the Father through the Son in the Holy Spirit. Without this perspective, the importance of religious singing can never be emphasized with enough conviction. The Hesychast Fathers had the same view on chanting, emphasizing in their writings that singing contributes to the monk's effort to keep his mind united with God.

\section{References}

1. Cabasila, Nicolae, Despre viaţa in Hristos (About Life in Christ), Ro. transl. by Pr. Prof. Dr. Teodor Bodogae, Bucharest, Editura Institutului Biblic, 1997.

2. IDEM, Tâlcuirea dumnezeieştii Liturghii (Explanation of the Divine Liturgy), Ro. transl. by Pr. Prof. Dr. Ene Branişte, Bucharest, Editura Institutului Biblic, 1997.

3. DiOnisie AREOPagitul, Despre Ierarhia Bisericească (About Church Hyerarchy), in Opere complete (Complete Works), transl. introd. and notes by Pr. Prof. Dr. Dumitru Stăniloae, Bucharest, Editura Paideia, 1996.

4. Filocalia (Philokalia), vol. 1, transl.,introd and notes by Pr. Prof. Dr. Dumitru Stăniloae, Sibiu, Institutul de Arte Grafice „Dacia Traiană”, 1947. 
5. Filocalia (Philokalia), vol. 7, transl., introd and notes by Pr. Prof. Dr. Dumitru Stăniloae, Bucharest, Edit. Institutului Biblic, 1977.

6. Filocalia (Philokalia), vol. 8, transl., introd. and notes by Pr. Prof. Dr. Dumitru Stăniloae, Bucharest, Edit. Institutului Biblic, 1979.

7. Sfântul MAXIM MĂRTURISITORUL, Mystagogia, Ro. transl. and presentation by Pr. Prof. Dr. Dumitru Stăniloae (with the title Cosmosul şi sufletul, chipuri ale Bisericii-The Cosmos and the soul, faces of the Church) in „Revista Teologică” (,Theological Magazine") (Sibiu), XXXIV (1944), nr. 7-8.

8. BIZĂU, Ioan, Imnografia şi cântarea liturgică în mistica sacramentală a Sfântului Nicolae Cabasila (Hymnography and liturgical chanting in the sacramental mysticism of St. Nicholas Kabasilas), in Studia Universitatis Babeş-Bolyai, Theologia Orthodoxa, XLIV, 1-2/1999.

9. BRANIŞTE, Ene, Explicarea Sfintei Liturghii după Nicolae Cabasila (Explanation of the Holy Liturgy according to St. Nicholas Kabasilas), Bucharest, Editura Institutului Biblic, 1997.

10. ŠPIDLIK, Tomáš, Spiritualitatea Răsăritului Creştin. II.Rugăciunea (Spirituality of Eastern Christianly. II Prayer), Ro. transl. by Diac. Ioan I. Ică jr., Sibiu, Editura Deisis, 1998.

11. StĂniloAe, Dumitru, Mitropolitul Teolipt al Filadelfiei. Viaţa şi scrierile (Metropolitan Theoleptos of Philadelphia. Life and Works), în Filocalia (Philokalia), vol. 7, Bucharest, Editura Institutului Biblic, 1977.

12. StăniloAe, Dumitru, Sfântul Grigorie Sinaitul. Viaţa lui (St. Gregory of Sinai. His life), în Filocalia (Philokalia), vol. 7, Bucharest, Edit. Institutului Biblic, 1977.

13. VinTILESCU, Petre, Liturghierul Explicat (Hieratikon Explained), Bucharest, Editura Institutului Biblic, 1972. 